\title{
Petrarch's Liber sine nomine and a Vision of Rome in the Reformation
}

\author{
ROBERT COOGAN
}

In his "Coronation Oration" (1341) Petrarch credits his ardent love of Rome for sustaining him in his laborious task of reviving poetry, and, to glorify his queen of cities, he chose to be crowned there rather than in Paris. ${ }^{1}$ However, the talismanic letters S.P.Q.R. (Senatus Populusque Romanus) disappear during the composition of the Liber sine nomine. Between 1347 and 1354, at a time when thoughts of conversion filled his mind, he composed this book of letters on the papacy, a book so violent that he removed all names from it and planned for its dissemination only after his death. ${ }^{2}$ The early letters show Petrarch's brighest vision, the renaissance of a constitutional Roman republic under the heroic Tribune, Cola di Rienzo. ${ }^{3}$ After the tragic fall of Cola in December of 1347, Petrarch's hopes were dashed, and Letter IV shows him turning to monarchs as the only logical saviours of Italy. He replaced his dream of a Christendom united through the efficacy of the Roman plebs with a dark vision in which the papal Curia is the new Babylon and the harlot of Revelation. Petrarch centres his invention on a metonomy in 1 Peter 5 and in Revelation: "And there followed another angel, saying Babylon is fallen, is fallen, that great city, because she made all nations drink of the wine of her fornication (14:8)." Through reliance on this metonomy and Revelation, Petrarch signals that his vision participates in a tradition of invective, the Romdiatribe ${ }^{4}$ The Liber sine nomine's contribution to the genre attracted the reformers in the Renaissance because of Petrarch's extraordinary popularity, his nationality and laureateship, and his moving eloquence. ${ }^{5}$ Petrarch's skill with invective led Erasmus to rank him alongside Homer, Plato, Aristotle, Demosthenes, Seneca, St. Jerome, and Politian. ${ }^{6}$ He has been seen as a prototype of Martin Luther ${ }^{7}$ because some reformers, reading their cause in the Liber sine nomine, used it in their polemical treatises, and thus engaged it in one of history's most significant events - the weakening of the ecumenical authority of the Roman Catholic Church. But this is only one of the many ironies associated with Petrarch - in the trecento he labored for the rehabilitation of Roman values by synthesizing them with Christian ones, in the cinquecento his reputation figures in the disintegration of a Romanized Christendom. 


\section{2 / Renaissance and Reformation}

The relationship between the Liber sine nomine and Petrarch's life offers another irony. To say nothing of the benefits derived from living in highly civilized Avignon at a time when Italy had nothing comparable, one must wonder how he could vilify the popes and the Curia that gave him his livelihood? He owed to them his cherished otium litteratum which freed him not only to pursue fame but to write these offensive letters. Petrarch had accepted canonries in Lombez, Pisa, Parma, Padua, Modena, and Monselic; chaplaincies to Cardinal Giovanni Colonna, King Robert of Sicily and Queen Joan of Naples; and an archdeaconate in Parma. Since he took possession and practised at Parma and Padua and since he relied on procurators to collect his revenues at the other benefices, he clearly consented to the pluralism that was forbidden by Church law and that chiefly caused the Avignon Papacy's notoriety. His treatment of Clement VI provides a typical example of Petrarch's questionable behavior. Although given too much to spectacle and munificence, Clement VI was an intelligent, charitable, and effective pope who offered Petrarch a secretaryship as well as a bishopric. At the very time Clement was granting favors to Petrarch's Italian friends and a canonry at Verona to Giovanni, the poet's illegitimate fifteen-year-old son, Petrarch tarnishes the Pope's reputation by comparing him to Nimrod in Letter VII. Yet in Rerum memorandarum libri he describes him as an excellent pastor. ${ }^{8}$ Petrarch appears to behave like the clericus aulicus, a medieval type of parasite that flourished in Avignon.

But the verdict on Petrarch need not be so harsh; for he openly, though less violently, criticized the papacy in his Bucolicum carmen, his De vita solitaria, and in scattered passages in his Epistolae familiares - works widely disseminated. He refused papal secretaryships, bishoprics, and any role that entailed the cure of souls or the loss of his freedom. Because there is very little indication of avarice in Petrarch and because he performed some useful ambassadorial roles for the Chruch, Wilkins thinks Petrarch should not be censured. In adopting the ecclesiastical profession, Petrarch was, according to Wilkins, entitled to a fair share of the common ecclesiastical inheritance. ${ }^{9}$ Furthermore, when one views the Liber sine nomine from the perspective of Petrarch's opus, his noteworthy accomplishments distinguish him from the courtly "hanger-on." The perfection of his love lyrics established him as the genre's master and enriched the literatures of Europe. By discovering and editing texts like Cicero's Pro Archia and Livy's Decades and by improving the style of Latin writing, he earned the title "Father of Humanism." In addition he was recognized as a notable apologist for the independent intellectual and as a major advocate of Christian Stoicism. Finally, Petrarch's francophobia further qualifies his role as ecclesiastical critic. Like Dante and many other Italians, Petrarch's immediate family suffered with French ascendancy. It must have galled him to witness the weakening of the Italian influence in the Curia when Clement VI created twelve cardinals at a stroke, 
nine of whom were French, four of whom were relatives. In begging Urban $\mathrm{V}$ to return to Rome, Petrarch blames the plight of the city on the papacy's absence:

In your absence ... peace is exiled; civil and external warfare rages; dwellings are prostrate; walls are toppling; churches are falling; sacred things are perishing; laws are trodden underfoot; justice is abused; the unhappy people mourn and wail, calling with loud cries upon your name. Do you not hear them?... Must the Queen of Cities be forever widowed? ... How can you sleep, under your gilded beams, on the bank of the Rhone, while the Lateran, the Mother of all churches, ruined and roofless, is open to the wind and rain, and the most holy shrines of Peter and of Paul are quaking, and what was once the Church of the Apostles is but a ruin and a shapeless heap of stones? ${ }^{10}$

In this letter he tries to disarm French hostility to residence in Italy by elaborate praise of his native land. These views and similar ones in another letter to Urban V (Seniles, IX, i) provoked an attack on Petrarch and Italy by a follower of Cardinal Gui de Boulogne, Jean de Hesdin, who ignored Petrarch's arguments that the rightful seat of the Empire and the Church was at Rome. Defending himself in Invective contra eum qui maledixit Italie, he echoes the vituperation of the Liber sine nomine and shows the depth of his contempt for the French. In evaluating Petrarch's attitude toward the papacy, one must take into account his disdain for the French, his violation of Church law on residency, and his contributions as a poet, humanist, and philosopher.

In his own day, Petrarch's animosity toward the Curia in Eclogues VI and VII of the Bucolicum Carmen led influential prelates to interrogate him. As he states in the Preface to the Liber sine nomine, he managed to change the drift of conversation when they questioned him on passages critical of them. It was this episode that led him to remove all names from the Liber sine nomine since in it he lacks the protection afforded by the veil of his pastoral allegory. A contemporary biographer of Petrarch, Filippo Villani (ca. 1325-1405), supports the notion that Petrarch was a very severe persecutor of clerical avarice and ambition and that he had gathered in Liber sine nomine letters that specifically treat ecclesiastical depravity. ${ }^{11}$ Other early biographers like Luigi Peruzzi, Domenico Bandini, Petrus Paulus Vergerius, Girolamo Squarciafico, Alessandro Vellutello, Giovan Andrea Gesualdo, Lodovico Beccadelli, and Guillaume de Roville recognize Petrarch's criticism of the papacy. They either refer to the Liber sine nomine or else remark about his aversion for the Avignonese court and his longing for the papacy's return to Rome. It seems that those who wish to understand Petrarch's role vis à vis the Church should accept the guidance of these biographers who see him as a persecutor or critic of vicious conduct. It would be imprecise to term him a reformer, because he proposed no changes in the Church's dogma or structure. In fact, his treat- . ment of an Averroist indicates a dread of heresy and a vigorous defense of traditional doctrines. ${ }^{12}$ In spite of the vast psychological distance between 
Petrarch and Catherine of Siena, he was as orthodox as she and had similar ideas on the papacy. They held that the Popes at Avignon were successors to Peter who should return the papacy to Rome and who should pacify Europe by leading a crusade against the Turks. ${ }^{13}$ Catherine's affection for Italy also figures in her thoughts on the papacy, but she recognized that such a sentiment was only a human consideration and was not nearly so intense about it as was Petrarch. In a letter to three Italian cardinals who supported the antipope, Catherine reprimanded them for not being as much influenced by a love of the homeland as were their French counterparts. ${ }^{14}$ Petrarch's desire to see the Emperor Charles IV return to Rome points to a major difference between him and Catherine. ${ }^{15}$ For a time, Petrarch held a view comparable to that in Dante's De monarchia, namely, that by divine ordinance the Emperor and the Pope should rule respectively the temporal and spiritual spheres from Rome. Catherine, who sees the Pope's involvement in temporal affairs as debilitating, does not find any particular significance in the Church's relationship between pagan Rome and contemporary Italy. Furthermore, as a mystic she relies solely on spiritual remedies to cure the Church of its afflictions. If the popes learn to love God, their neighbour, and themselves properly, the church will be purified of nepotism, simony, and the other abuses caused by pluralism. Although their education and experiences might suggest the differences between them, there has never been any reason to consider Petrarch less orthodox than Catherine.

When Petrarch's letters received considerable attention during the Reformation and Counter-Reformation, a similar view obtained. Reformers and Counter-Reformers note his criticism of clerical conduct, but none question his orthodoxy. Between 1496 and 1602, the Liber sine nomine - wholly or in part - was printed eleven times in collections of Petrarch's works or as separate entities. On various occasions, three sonnets from the Canzoniere Fiamma del ciel (CXXXVI), L'avara Babilonia (CXXXCII), and Fontana di dolore (CXXXVIII) - were printed with some of the Liber sine nomine, for these poems capture the spirit of the letters. In his edition of the Canzoniere (1551), Antonio Brucioli used his annotations on these sonnets for an attack on the Church. ${ }^{16}$ The violent indignation and the $a$ fortiori argument that juxtaposes the Curia's vice against the virtues of the primitive Church link the poems and the letters. It was only the Liber sine nomine and their epitome, these three sonnets, that were originally reviewed by the Congregation of the Index.

By the time Luther and Calvin became prominent, the Liber sine nomine had spread Petrarch's fame as a critic, and his invectives against Babylon on the Rhone were transferred to a Babylon on the Tiber. For example, next to the concluding words of Letter $X$ (auro Cristus venditur) in the copy of the Opera of 1496 in Cornell University's Fiske Collection, a marginal gloss in a sixteenth-century hand states that Alexander VI sells the sacraments and 
sacred things. ${ }^{17}$ In 1508 the Waldensians presented a statement of their beliefs to King Ladislaus of Hungary. Their creed came under attack by a theologian, Augustine, whose position, in turn, some Waldensians disputed in Excusatio fratrum Waldensium. In defense of their opposition to the papacy, the Waldensians quote passages from Letters VIII and XVIII. In the former, they offer Petrarch's argument that the Avignonese Babylon and its labyrinth surpass in evil all infernos of former ages; in the latter, the most intense letter in the collection, they present Petrarch's famous paraphrase and embellishment of Revelation's description of the Babylonian harlot fornicating with the kings of the earth. An abridgement of the paraphrase indicates the tone of Petrarch's invective:

... the worst of all things are there in Babylon on the fierce banks of the Rhone where the infamous prostitute fornicates with the kings of the earth. ... You indeed are small, Babylon, by the circuit of your walls; but in vice, in ambition, in venality, in the heaping up of all evils you are not only great, you are the greatest, you are immense. You are the mother of fornicators and the abomination of the earth, the impious mother of detestable offspring. ...

Dear friend, with that same Apostle listen to a voice from heaven: "And I heard another voice from heaven, saying: Go out from her, my people, that you be no partakers of her sins, and that you receive not of her plagues. ... Hear all those things which that Apostle has in that place, hear and flee if there is any escape route lest your innocence be crushed by the ruin of the guilty under the iniquities of Babylon of which there is no measure, no number, no weight. Not even an estimate. ${ }^{18}$

By the way of conclusion, the Waldensians state that these things are said in other letters spread abroad in all lands. ${ }^{19}$

As the forces let loose at Wittenberg gained momentum, Petrarch's reputation as a critic of the papacy increased greatly. In 1523 Paulus Angelus associated the sonnets with the renovation of Christianity; ${ }^{20}$ and in 1535 , Johannes Odonus, an Italian humanist who went to Germany to study theology, wrote to Erasmus that Petrarch's critical words can still be applied to the condition of the Church, for there has been no improvement in conduct for the last two hundred years. ${ }^{21}$

At about mid-century while the Council of Trent was in session, the letters and sonnets reached their high point of influence. In 1555, Petrus Paulus Vergerius, the younger, published an edition of the Liber sine nomine. Vergerius, a papal nuncio and Bishop of Capodistria, converted to the Lutheran cause and became theological advisor to the Lutheran Duke of Württenberg and one of the Reformation's most prolific pamphleteers. In the preface to his edition, he states that the Church which so long gloried in Petrarch's genius, eloquence, and erudition now wants him in the catalogue of the heretics. The impostures of the popes have been laid bare; and now, like Cain, they resort to the cruelty of fire, sword, and proscription. The grave and 
learned Petrarch, Vergerius writes, exposed over two hundred years ago the very vices that still flourish in the papal court. ${ }^{22}$ In 1556 , Vergerius published the Catalogus haereticorum which discusses Dante's De monarchia and compares the anti-papal ideas of Dante, Petrarch and Occam. In order to advertise views of prominent Italians on the papacy, Vergerius published in 1557 a popular translation in Italian of some of the letters, the three sonnets, and eighteen anti-papal stanzas composed by Francesco Berni, a secretary of Pope Clement VII. He translates from Letter V the metaphorically rich passage that praises the apostolic fishermen and disparages their Avignonese descendants who use papal bulls to net and devour Christians. Going then to Letter XIV, he refers to the absence of all good in Avignon and enumerates the many places filled by lies. He renders a lengthy portion of Letter XVII with its many ironies and paradoxes - Christ is crucified anew in Avignon, Constantine is chided for his donation, the Christians are lambs devoured by the wolves in the Curia, and the papal military leader is a new Hannibal descending upon Italy. The following passage on Christ's crucifixion, like the paraphrase of Revelation, is a sample of Petrarch's invective that would be especially appealing to the reformer:

... What, I ask, difference exists between those enemies of Christ and these Pharisees of our day. ... They crown Him with briars of impious riches and pollute Him with kisses from most impure mouths; they pursue Him with viperish hissings and strike Him with the lance of poisonous deeds; and, as far as they can, they drag Him - mocked, naked, helpless, scourged - again and again to Calvary; and by their culpable connivance they again fix Him to the cross. ${ }^{23}$

Vergerius then inserts brief passages from Letters VIII and X, states that Judas and his pieces of silver would be more welcome in Avignon than Christ, and finally translates the passage in Letter XVIII that paraphrases Revelation. In conclusion, he claims that he has rendered Petrarch faithfully and that the reader can find similar sentiments in the other letters. ${ }^{24}$ Even though the translations are faithful, this appraisal is not altogether accurate. Vergerius makes an addition to Letter XVIII, - i.e., he speaks of Avignon's flying asses and earthbound eagles, its elect wolves and fated lambs, its bandit Christ and its protector and judge Beelzebub. In these antitheses, Vergerius, a polemicist noted for his coarseness and a habitual skepticism, imitates the Petrarchan invective. Vergerius then presents the three sonnets and the stanzas of Berni.

In 1562, Mathias Flacius Illyricus uses the letters in Catalogus testium veritatis, an anthology of anti-papal statements made prior to the Reformation. Flacius (1520-1575) studied at Wittenberg under Luther and Melanchthon and dedicated his ecclesiastical history to England's Queen Elizabeth to encourage her to embrace a pure Christianity. To show how Petrarch hated Avignon, he quotes the passages stating that Christ is sold for gold and that the papacy is the Babylonian whore. He then presents the three sonnets and the 
canzone, "Mai non vo' piu cantar com' io soleva," accompanied by Johann Dietrich's Latin translation of the poems. ${ }^{25}$ In an undated work - Das der Pabst mit seinem hoffe die rechte Babilon und Babilonische Hure sey Flacius presents his translation in German of Letter XVIII. At the end of the text, he makes the following exhortation and prayer to German readers:

From this and similar writings, dear Christian reader, you can clearly see that there were and always will be devoted Christians who have recognized and cursed the shameful pope as the true Anti-Christ and the Babylonian whore. Therefore, woe, woe, and woe again to all those that support confirm, or help the Anti-Christ and his tyranny in any manner. The angel of the Apocalypse cries - flee, flee from Babylon in order to escape punishment, for its sins have arisen to heaven. Whosoever does not heed the admonition of the heavenly Father and participates in the sins of Anti-Christ will have to bear the anger of God. May the eternal and merciful God keep his own from these and other sins. Amen ${ }^{26}$

Petrarch's final important appearances as a critic of ecclesiastical abuses in the Renaissance are among the Anglicans and Calvinists. John Philpot (151655), burned at the stake during Mary Tudor's reign, translated an oration by Celio Secondo Curione, Pro vera et antiqua Ecclesiae Christi auctoritate. Curione, a Piedmontese convert to Protestantism, held the chair of Rhetoric at Basel where he edited Livy and Seneca, made the famous revision and expansion of Nizolius' Thesaurus, and translated into Latin Guicciardini's Storia d'Italia. His pasquinades written in Latin and Italian and translated into English, French, and German effectively ridiculed the Roman cause. Philpot's translation brings the "noble poet Petrarch" forward to reprove the Romish congregation of the pope. Philpot gives Curione's Italian verses of two of the Babylonian sonnets and provides his own exact English translation. The passages from Canzoniere 136 and 138 stress the depravity of Rome and its contrast with the innocence of the early church. Philpot gives the impression that Petrarch speaks not of Avignon, but of Rome. ${ }^{27}$

In The Defense of the Apology of the Church of England (1567-1569), John Jewel makes use of the violent passages where Petrarch calls Avignon the whore of Babylon, the mother of all idolatry and fornication. He then identifies the Pope with the Anti-Christ. ${ }^{28}$ Jewel also quotes the sonnet, Fontana di dolore, a poem translated into English many years earlier, possibly by a member of the Wyatt family.

In 1601 and 1602, Calvinists at Lyons made five printings of the letters; those at Geneva published the sonnets in 1627. After the second-half of the sixteenth century, the Congregation of the Index was placing such severe restrictions on almost all types of printing that Petrarch's works were printed chiefly at Protestant centres like Lyons, Geneva, Basel, Strasbourg, and Cologne, a further indication of their reception in the Reformation. The standard edition of Petrarch's Opera was published in Basel (1554) by 
Johannes Herold, a rabid anti-Catholic who made the first translation in German of Dante's De monarchia.

From this glimpse of the Liber sine nomine among the reformers, one may conclude that the Lutherans and Calvinists sought to make Petrarch a precursor of the Reformation not only for the ferocity of his invectives but also for his primitivism, since Petrarch and the reformers sought greater simplicity and purity in the apostolic successors. In addition, the Liber sine nomine's embellishment of the Avignon papacy as the Babylon and whore of the Apocalypse captured the imagination of the reformers who applied to Rome what Petrarch had directed against Avignon.

Petrarch's reception north of the Alps obviously caused considerable consternation and confusion in Rome. The Congregation of the Index faced a dilemma: how can one proscribe Petrarch who was often eulogized for his saintliness and for his affection for the Roman Catholic Church? How can Italy's most venerated author - in the sixteenth century there were 167 editions of the Canzoniere and only thirty of the Divina Commedia - be placed on the Index by cultivated Italian prelates? Furthermore, would not the interdict on Petrarch substantiate the claims of the Protestants, namely, that Petrarch was indeed a precursor of the Reformation? The treatment afforded Petrarch by the Congregation of the Index reveals the enigma it faced, and it is not until Bellarmine undertakes a systematic defense of Petrarch that the position of the Counter-Reformation on him becomes clearly defined.

It appears that the Italian translation of the Liber sine nomine by Petrus Paulus Vergerius, the younger, led Pope Paul IV to take steps against Petrarch. Through Paul's instigation, Vergerius' rendition of Petrarch was placed on the Indexes of 1559 and 1560 . The proscription applied only to those parts of Petrarch critical of the papacy. From this time until 1722, the three sonnets were deleted from editions of the Canzoniere printed in Catholic countries. In some editions of the Index, e.g., Parma (1580) and Rome (1590), the three sonnets were singled out for deferential treatment - they are listed in a special appendix. In the Roman Index of 1632 , specific passages from the letters are condemned; the Spanish Indexes of 1612 and 1667 make more comprehensive proscriptions. Although the Italian leniency comes in part from national sympathies, most felt that Petrarch's Opera were basically sound. The font must not be considered contaminated if one finds a few impure drops. Minturno, a bishop who was at Trent, makes a further distinction in regard to Petrarch in his L'Arte Poetica (ca. 1563), a reworking of Aristotle in the spirit of the Counter-Reformation. He claims that the poems should be deleted from the Canzoniere, for they lack a reverence for the church that should be shown in word and deed. When appealing to the letters, however, he stresses that Petrarch's attacks are against Avignon and not Rome. ${ }^{29}$

St. Robert Bellarmine, defending Pope Sixtus V and the papacy from the attacks occasioned by Perrot's use of Petrarch, Dante, and Boccaccio in his 
Avviso piacevole dato alla bella Italia ${ }^{30}$ makes the most thorough apology for them in the Counter-Reformation. In order to establish his perspective, Bellarmine objects to seeing them not as poets, but as prophets. He feels that love songs and dream-visions are not to be exempt from contradiction and criticism. He points out that Dante, as a Ghibelline, was an enemy of the popes. Bellarmine feels inclined to laughter when his opponent commends the sanctity of Petrarch and Boccaccio. Had not Petrarch himself blushed for his shameful love? After speaking of the harmful effects of imaginative works on youth, Bellarmine explains that Pius V demanded the deletion of three sonnets - songs written not without great perturbation of spirit - because he feared Petrarch would be used to confirm errors. In treating the Liber sine nomine which designated the papal Curia as a Babylon, he employs a recurring argument in Counter-Reformation apologetics, namely, Petrarch condemned the vices of men, not the pope or the papal chair. ${ }^{31}$ Bellarmine goes on to say that Petrarch never had in mind what the Church's adversaries now say, namely, the Papacy is the Anti-Christ. If Petrarch thought his works would lead to error, he would not be offended by Pius V's proscription; in fact, he would cast the works into the fire with his own hand. To prove Petrarch's orthodoxy, Bellarmine makes an impressive list of quotations from Petrarch attesting to the soundness of his dogma and revealing his reverence for Peter's Chair. In brief, Bellarmine argues that Petrarch spoke not of faith, religion or ecclesiastical authority, but of vices that flourished in his day. ${ }^{32}$

At the beginning of the seventeenth century, the Jesuit Jakob Gretser (1562-1625) echoes Bellarmine's argument. After noting that Petrarch's letters against the pope and Curia are found among all the sects, Gretser says that Petrarch, abused by the heretics, does not write against the priesthood, but against the vices of men. He recommends his reader see Bellarmine's writings to realize how much Petrarch honored Rome, the Pope, the Church, and the Apostolic Seat. ${ }^{33}$

Among the Protestants, Bellarmine's position evoked a response in Simon Birckbek's The Protestant's Evidence (1635). Praising Petrarch for his knowledge of scripture and for the revival of learning, the English divine refuses to accept Bellarmine's distinction between the papal court and the Church. Admitting that Pius $\mathrm{V}$ was galled by the three sonnets, Birckbek insists that the letters are not in a poetical vein. He then translates into English some passages from the famous paraphrase of the Apocalypse. Birckbek's marginalia contain Petrarch's Latin passages. To add weight to his position, he quotes also from St. Brigid, a canonized saint who calls the pope a murderer of souls, a person more abominable than the Jews, more "despitefull" than Judas, more unjust than Pilate and worse than Lucifer. ${ }^{34}$

In conclusion, it is clear that reformers considered the Liber sine nomine as evidence of papal corruption. Comments by the Waldensians, Flacius, and Gretser indicate wide-spread dissemination of the texts. Both sides also wanted the distinguished Petrarch as an ally, and neither questioned the 


\section{0 / Renaissance and Reformation}

historicity of the letters or the orthodoxy of Petrarch. Furthermore, the energy of the invective captured imaginations and nourished the Romdiatribe, making conspicuous a dark vision of Babylon transferred from the Rhone to the Tiber. Finally, the dire prophecies of the most famous eighteenth letter were perceived as predictions of the Reformation.

\section{University of Maryland}

\section{Notes}

1 Petrarch, "Coronation Oration," trans. by Ernest Hatch Wilkins in Studies in the Life and Works of Petrarch (Cambridge, Mass., 1955), pp. 304-05.

2 The standard edition and a recent translation use Liber sine nomine rather than Epistolae - P. Piur, Petrarchas 'Buch ohne Namen' und die päpstliche Kurie (Halle, 1925). See Norman P. Zacour, Petrarch's Book without a Name: A Translation of the "Liber Sine Nomine" (Toronto, 1973), p. 12. Quotations from the Liber sine nomine will be from Piur's edition and translations will be mine.

3 For a translation of Epistolae Variae (XLVIII), Petrarch's panegyric on the rebirth of a Roman republic under Cola, see Mario E. Cosenza, Francesco Petrarca and the Revolution of Cola di Rienzo (Chicago, 1913), pp. 16-44.

4 See Arturo Graf, Roma nella memoria e nella immaginazioni del Medio Evo (Turin, 1915), p. 282 and Chapter XX, "Roma e al Chiesa," pp. 679-90. For medieval attacks centering on the venality of the papacy, see John A. Yunck, "Economic Conservatism, Papal Finance, and the Medieval Satires on Rome," Medieval Studies, 23 (1961), 334-51. For Renaissance Italian humanists' "rhetoric of reproach" against the pope, see John M. McManamon, "The Ideal Renaissance Pope: Funeral Oratory from the Papal Court," Archivum Historiae Pontificiae, 14 (1976), 43-45. For further study of criticism of the papal court by Italian humanists, see John W. O'Malley, Giles of Viterbo on Church and Reform (Leiden, 1968), pp. 132-35 and Praise and Blame in Renaissance Rome (Durham, 1979), pp. 184-94 and 211-16. See also Robert Brentano, Rome Before Avignon: A Social History of Thirteenth-Century Rome (New York, 1974), pp. 88-89.

5 Petrarch, especially because of his De remediis utriusque fortunae, his Latin version of Boccaccio's Griselda, and his Psalmi poenitentiales, was the most widely read Neo-Latin author up to the days of Erasmus. For evidence on the reception of his Latin works throughout the English Renaissance, see Robert Coogan, "Petrarch's Latin Prose and the English Renaissance," Studies in Philology, 68 (1971), 270-91.

6 Opus Epistolarum Des. Erasmi Roterodami, ed. P.S. Allen et al. (12 vols.; Oxford, 1906-58), II, 92.

7 Ugo Chiurlo, "Le Idee Politiche de Dante Alighieri e di Francesco Petrarca," Il Giornale Dantesco, 16 (1908), 106.

8 Petrarch, Rerum memorandarum libri, ed. G. Billanovich (Florence, 1943), p. 49.

9 Ernest Hatch Wilkins, "Petrarch's Ecclesiastical Career," in Studies in the Life and Works of Petrarch (Cambridge, Mass., 1955), pp. 3-32.

10 The passage from Epistolae Seniles (VII, I) is translated by Ernest Hatch Wilkins, Life of Petrarch, (Chicago, 1961), p. 201.

11 Filippo Villani in Le vite di Dante, Petrarca, e Boccaccio, ed. Angelo Solerti in Storia Lettararia D'Italia (11 vols.; Milan, 1897-1926), IV, part ii, 279.

12 See Epistolae seniles V, 2 [3]. Part of this letter to Boccaccio is translated in "An Averroist Visits Petrarca," in The Renaissance Philosophy of Man, ed. by E. Cassirer, P.O. Kristeller, J.H. Randall, Jr. (Chicago, 1948), pp. 140-41.

13 See "Il successor di Carlo, che la chioma" (27) and "O aspettata in Ciel beata et bella" (28) in the Canzoniere. For Catherine's call for a return to Rome and for a crusade, see Lettere di Santa Caterina, commentary by N. Tommeseo (Rome, 1973) Letter XXXI, pp. 175-78 and Letter XLV, pp. 235-38. 
14 Ibid., Letter LXXXII, pp. 417-25.

15 For Petrarch's advice to the Emperor, see Epistolae familiares, X, I.

16 Petrarca, Canzoniere, ed. Lucantonia Ridolfi with annotations of Antonio Brucioli (Lyon, 1551).

17 The marginalia are in the first of three copies of this edition. See Mary Fowler, Catalogue of the Petrarch Collection bequeathed by Willard Fiske (New York, 1916), p.2.

18 Petrarch papaphrases Revelation 17 and 18. The complete passage in Piur (pp. 230-31) is as follows: "Tu autem gaude, contrario saltem magistra uirtutum! Gaude inquam, et ad aliquid utilis inuenta gloriare, bonorum hostis et malorum hospes atque asilum, pessima rerum Babilon, feris Rodani ripis imposita, famosa dicam an infamis meretrix fornicata cum regibus terre! Illa equidem ispa es quam in spiritu sacer uidit Euangelista. Illa eadem, inquam, es, non alia, sedens super aquas multas, siue ad literam tribus cincta fluminibus siue rerum atque diuitiarum turba mortalium, quibus lasciuiens ac secura insides, opum immemor eternarum, siue, ut idem qui uidit exposuit, populi et gentes et lingue aque sunt, super quas meretrix sedes. Recognosce habitum: Mulier circumdata purpura et coccino et inaurata auro et lapide pretioso et margaritis, habens poculum aureum in manu sua, plenum abominatione et immunditia fornicationis eius. Noscisne teipsam, Babilon? Nisi illud forsan errorem facit quod in illius fronte scriptum erat 'Babilon magna!' tu uero Babilon parua es. Parua utique murorum ambitu, sed uitiis et ambitu animorum et infinita cupidine cumuloque malorum omnium non magna modo, sed maxima, sed immensa es. Et certe quod sequitur, tibi uni conuenit, non alii: Babilon mater fornicationum et abominationum terre. Mater impia partuum pessimorum, quando quicquid usquam terrarum abominable, quicquid fornicatorium ex te prodit, et cum semper parias semper tumens et talium plenus ac grauidus uterus tuus est. Si nunc quoque dissimulas, audi reliqua. Et uidi, inquit, mulierem ebriam de sanguine sanctorum et de sanguine martirum Jesu. Quid siles? Aut aliam hoc sanguine ebriam ostende aut omnino, si potes, te hanc ebriam nega. Vera enim Euangeliste et Apostoli uisio sit opertet. Qui si te in spiritu uidens miratus est admiratione magna, quanta nos admiratione perfundimur qui aperte oculis te uidemus? Ex omnibus quidem fornicationibus tuis, de quibus biberunt omnes gentes et reges terre, et ex omnibus abominationibus quid expectes, nisi quod Joannes idem ait: Cecidit, cecidit Babilon magna et facta est habitatio demoniorum. Nota sunt que sequuntur. Vere iam talis facta es. Quanto enim homo perditus et desperate nequitie demone melior? Vero habitatio, imo regnum demonum facta es, qui suis artibus, humana licet efigie [sic], in te regnant.

Tu uero, amice, cum eodum Apostolo audi uocem aliam de celo dicentem: Exite de illa, popule meus, et ne participes sitis delictorum eius et de plagis eius non accipiatis; quoniam peruenerunt peccata eius usque ad celum et recordatus est Dominus iniquitatum eius. Quantum glorificauit se et in delitiis fuit, tantum date illi tormentum et luctum, qui in corde suo dicit: Sedeo regina, uidua non sum et luctum non uidebo. Ideo in una die uenient plage eius, mors et luctus et fames, et igni comburetur, quia fortis est Deus, qui iudicabit illam."

19 Anon. "Expositio fratrum Waldensium," in Edward Brown, Fasciculus rerum expetendarum et fugiendarum (2 vols., London, 1960), I, 188-89.

20 Paulus Angelus, Epistola Pauli Angeli ad ... Clementem ... papam septimum, ..... Sonetti de messer Francesco Petrarca Fiorentino sopra la presente renovatione del Cristianesimo (n. p., 1523).

21 Erasmus, Opus Epistolarum, ed. P.S. Allen et al. (12 vols.; Oxford, 1906-58), XI, 93.

22 Petrus Paulus Vergerius, the younger, Francisci Petrarchae ... Epistolae XVI. Quibus plane testatum reliquit, quid de Pontificatu, et de Rom. Curia senserit. Excerptae ex eius libris, qui in manibus hominum versantur (Strasbourg, 1555).

23 The translation is mine. The complete passage in Piur (p. 221) is as follows: "Vides en populum non modo Cristi aduersarium, sed, quod est grauius, sub Cristi uexillo rebellantem Cristo, militantem Satane et Cristi sanguine tumidum atque lasciuientum et dicentum: Labia nostra a nobis sunt, quis noster Dominus est? Populum duricordem, impium, superbum, famelicum, sitientem, hianti rostro, acutis dentibus, procuruis unguibus, pedibus lubricis, pectore saxeo, corde chalybeo, plumbea uoluntate, uoce melliflua, populum cui proprie conuenire dixeris non modo Euangelicum illud atque propheticum: Populus hic labiis me honorat, cor autem eorum longe est a me, sed illud etiam Jude Jscariotis, qui Dominum suum prodens et exosculans aiebat: 'Aue Rabbi,' et Judeorum qui indutum purpura, coronatim spinis percutientes et conspuentes illusione amarissima, flexis poplitibus adorabant et salutabant: 'Aue rex Judeorum!', quem neque et Deum neque ut regem diunis aut humanis honoribus, sed ut reum mortis ac blasphemum, contumeliis dignum atque suppliciis inhumano iuditio destinarant. Quid enim, quid oro, aliud assidue geritur hos inter Cristi hostes et nostri temporis 


\section{2 / Renaissance and Reformation}

Phariseos? Nonne etenim Cristum ipsum, cuius nomen die ac nocte altissimis laudibus attollunt, quem purpura atque auro uestiunt, quem gemmis ornant, quem salutant et adorant cernui, eundem interea emunt, uendunt, nundinantur, eundem quasi uelatis oculis non uisurum et impiarum opum uepribus coronant et impurissimi oris sputis inquinant et uipereis sibilis insectantur et uenenatorum actuum cuspide feriunt et, quantum in eis est, illusum, nudum, inopem, flagellatum iterum atque iterum in Caluariam trahunt ac nefandis assensibus cruci rursus affigunt."

24 Petrus Paulus Vergerius, the younger, Alcuni importanti luochi tradotti fuor delle epistole latine di $M$. Franceso Petrarca (n. p., 1557), A3-B1.

25 Matthias Flacius Illyricus, Catalogus testium veritatis (Strasbourg, 1562), p. 508.

26 Matthias Flacius Illyricus, Das der Pabst mit seinem hoffe die rechte Babilon und Babilonische Hure sey. Durch den hochgelarten Franciscum Petrarcham einen Welschen, der fur 250 jarn gelebet hat. (n. p., n.d. [15-?]).

27 Celio Secondo Curione, Defense of the True and Old Authority of Christ's Church, trans. by John Philpot in The Examinations and Writings of John Philpot (Cambridge, 1842), pp. 418-30.

28 The Works of John Jewel, ed. John Ayre (4 vols.; Cambridge, 1845-50), IV, 628, 740.

29 Antonio Minturno, L'Arte Poetica (Naples, 1725), p. 125.

30 Francois Perrot, Avviso piacevole dato alla bella Italia (Monaco [spurious place of printing], 1586).

31 Robert Bellarmine, "Appendix ad Libros de Summo Pontifice quae continet responsionem ad librum quemdam anonymum eujus titulus, 'Aviso piacevole dato alla bella Italia'," in Omnia opera (12 vols.; Frankfurt, 1965), VI, 535. The following passage contains the core of Bellarmine's defense: "Transeo nunc ad ea, quae ex Francisco Petrarcha in medium adversarius protulit, ea sunt partim cantica quaedam, partim fragmenta epistolarum, sed omnia in unam atque eandem sententiam conveniunt, ut videlicet Romanam Curiam multorum vitiorum accusent, ac propterea etiam Babylonem quamdam nominari posse affirment. Fateor illa in libris Petrarchae exstare, sed quae vitia hominum damnent, non Pontificum, aut sedis Aspostolicae dignitatem imminuant, id quod ipse testatur lib. XI. senilium epistolarum ad Franciscum Brunum Pontificis Maximi secretarium scribens. Nam cum admoneretur, ne tam multa scriberet in Cardinales, aliosque Rom. Curiae praelatos, respondit, se non homines, sed vitia hominum insectari, neque id facere, quod sibi nocuerint, sed quia injuriam male vivendo faciunt Romanae Urbi, Ecclesiae Dei, Christo ipsi, atque Apostolis ejus Petro, et Paulo."

32 See Ibid., VI, 527-37 for the entire apology.

33 Jacob Gretser, "Examen Mysterii Plessa ani," in Omnia Opera (7 vols.; Ratisbonae, 1736), VII, 373.

34 Simon Birckbek, The Protestant's Evidence (London, 1635), pp. 61-66. 